\title{
Analysis and Mitigation of Strategic Risk Business Process by Considering Relationship between Risks: Case Study in Electricity Generation Companies
}

\section{Lalu Bramantias Gutama ${ }^{1}$, I Nyoman Pujawan ${ }^{2}$}

${ }^{1,2}$ Department of Technology Management, Faculty of Business and Technology Management, Institut Teknologi Sepuluh Nopember. Surabaya,60111, E-mail : goetama@gmail.com¹ ${ }^{1}$, pujawan@ie.its.ac.id ${ }^{2}$

Diterima: 08/08/2019

Direview: 18/10/2019

Diterbitkan: 28/11/2019

Hak Cipta @ 2019 oleh Penulis (dkk) dan Jurnal Sosial Humaniora (JSH)

*This work is licensed under the Creative

Commons Attribution International License (CC

BY 4.0).

http://creativecommons.org/licenses/by/4.0/

\section{Subject Area : Economy (Ekonomi)}

\begin{abstract}
This study analyzes the linkages between the causes of strategic risks of business processes which refer to the balance scorecard perspective in company $X$, one of electricity generation company. Prioritized 87 risk causes were identified at the outset using the House of Risk 1 method and the Pareto principle so that 17 dominant risk causes were obtained, which were then analyzed using the ISM method and then weighted using the analytic network process (ANP) method to obtain the new ARP value causes risk that had accommodated the relationship between the causes of risk. To make it easier for companies to prioritize the handling of the 17 risk-causing agents, a mitigation analysis was then carried out using the House of Risk 2 by considering the ranking of existing effectiveness to difficulty so that 8 effective strategies for handling agents causing risk were chosen.
\end{abstract}

Keywords: Analytic network process, Balance scorecard, House of Risk, Interpretive structural modeling, Strategic risk

\section{Introduction}

Strategic risk is the risk associated with the company's business strategy and plans going forward. This includes risks when entering a new business, expanding production, mergers and acquisitions, applying new technologies and the inability to anticipate competition. Referring to one expert in defining strategic risk, strategic risks are those unintended events or conditions such as changes in competitors' behavior, critical errors in internal process, and loss of technological capabilities that reduce managers' ability to implement their intended business strategies (R. Simon, 2000).

To achieve the company's strategic plan, Strategic Asset Management is established as an effort to provide direction and guidance in managing company assets that require a strategic approach, allowing companies to meet consumer needs, provide and maintain assets and achieve service results that are excellence. The strategic asset management plan is then translated into asset management objectives that are arranged in a balanced manner both externally and internally based on the balance scorecard principles 
relating to finance, customers, internal business processes and learning growth (PT. Pembangkitan Jawa Bali, 2016).

There is something interesting from a previous research journal written by Cheng, M. et al. (2018) with the title "The Interplay between Strategic Risk Profiles and Presentation Format on Managers' Strategic Judgments Using the Balance Scorecard" whose results showed that the effect of strategic risk profile was greater under an integrated approach than a stand-alone approach for managers' strategy recommendation judgments. From that, research does not consider any potential interrelationships that may exist between strategic risks. For example, different strategic risks may be correlated, and one strategic risk may amplify or mitigate the effect another strategic risk has on a company's strategy. From these suggestions, it is interesting to do interrelationship research that might appear between strategic risks in business processes which refers to the balance scorecard in company $\mathrm{x}$ which can be useful to prioritized risk mitigation more comprehensive and make greater impact in accuracy of long term planning and yearly planning. Another benefit that can be obtained from evaluating risk by considering interrelationship between cause of risk or risk agent under an integrated approach base on balance scorecard perspective is that the closer physical proximity between risk and performance information, the cognitively easier for managers to integrate this information ( F. H. P. \&. W. D. Hodge, 2010) (L. Maines, 2000). When managers are required to incorporate risks in their strategic judgments, they need to expand their understanding of these relationships to include risks in their causal reasoning (B. \&. K. S. Rehder, 2010) (B. Rottman, 2014).

\section{Literature Review}

\section{Balance Scorecard}

The Balanced Scorecard (BSC) translates a firm's mission and strategy into a set of understandable performance measures (indicators) so that the strategy could be understood, communicated and measured; thus, serving as a basis for all the activities. Moreover, the indicators allow monitoring the accuracy level of strategy implementation (Kaplan, R.S. and Norton, D.P, 1996). In order to respond to the firm's vision and strategy, the BSC uses four business perspectives. A financial perspective that establishes the financial objectives that must be attain in order to satisfy the shareholders' interests. Timely and accurate funding data will always be a priority, and managers will do whatever necessary to provide it. In fact, often there is more than enough handling and processing of financial data. With the implementation of a corporate database, it is hoped that more of the processing can be centralized and automated. But the point is that the current emphasis on financials leads to the "unbalanced" situation with regard to other perspectives. There is perhaps a need to include additional financial-related data, such as risk assessment and cost-benefit data, in this category (G. Talebnia, 2012).

Business Process of Company $\mathrm{X}$ is a summary of the activities and flow of activities needed to support the strategic objectives of company $\mathrm{X}$ using a Balance Scorecard that has 4 perspectives balance. Company $\mathrm{X}$ asset management Objectives as a translation of the strategic Asset Management Plan is structured in a balanced manner both externally and internally and relates to finance, customers, internal 
business process and learning growth as strategic challenges. Asset Management Objectives provides an overview of what the organization must do to maintain and or improve competitiveness and ensure the sustainability and goals that company $\mathrm{X}$ aims to achieve in the five-year period.

\section{House of Risk 1}

The House of Risk method considers that a risk agent or cause of risk can cause or influence more than one risk event so that in this method the risk probability used is the probability of the appearance of a risk agent, and the risk severity used is the severity of the risk event which will subsequently be used to quantify the potential aggregate risk of a risk agent. This can be explained as follows.

If $\mathrm{Oj}$ is the probability of occurrence of risk agent $\mathrm{j}, \mathrm{Si}$ is the impact if the risk event appears and $\mathrm{Rij}$ is the correlation between risk agent $\mathrm{j}$ and risk event $\mathrm{i}$, then the risk potential aggregate (ARP) of risk agent $\mathrm{j}$ is calculated following the formula (Pujawan, I.N. and Geraldin, L.H., 2009):

$\mathrm{ARP}_{\mathrm{j}}=O_{j} \sum_{i} S_{i} R_{i j} \ldots(1)$

\section{Interpretive Structural Modeling}

ISM approach consists of seven steps (Pfohl, Gallus and Thomas, 2011), namely (1) selection of elements relevant to the problem, (2) establishing contextual relation type, (3) construction of structural self-interaction matrix (SSIM) by pairwise comparison, (4) developing a reachability matrix from the SSIM and checking for transitivity, (5) level partitioning of reachability matrix, (6) drawing of digraph with removed transitivity links, (7) conversion of digraph into an ISM and checking of conceptual inconsistency.

\section{Analytic Network Process}

At this stage, the aim is to weigh the criteria formed in the ANP model (Pfohl, Gallus and Thomas, 2011). Based on the results of the ISM method, it can be obtained which criteria have a related relationship with each other between the variables that cause strategic risk.

Through the ANP method, it can capture the interdependence relationship between one risk and another in both the same cluster and different clusters. The purpose of using ANP in this study is to get the weight of each risk cause. The amount of weight can be obtained from paired comparisons between interrelated criteria. In addition, the purpose of using the ANP method is to get any of the risks that have the highest influence between the interrelationships between risks.

\section{House of Risk 2}

The second stage in the HOR method is phase 2 HOR, where some phase 2 will be selected for handling strategies that are considered effective to reduce the probability of the impact caused by risk agents. Selection of the handling plan to determine some parameter values using the survey method and FGD/PGD. The step in phase 2 of the HOR begins with the design of a handling strategy, looking for a large relationship between the handling strategy and the existing risk agents, calculating the value of Total Effectiveness (TEk) and Degree of Difficulty (Dk), and finally calculating the Effectiveness to Difficulty (ETDk) ratio to know the priority rating of existing strategies with the following stages:

a. Designing a handling strategy based on the prioritization that will be shown by the Pareto diagram, 
a number of management strategy plans will be recommended that can allow to eliminate or reduce the risk agent's appearance.

b. Correlation of Handling Strategies with Risk Agents

c. Calculation of Total Effectiveness and the results of the Degree of Difficulty calculation of the Total Effectiveness of all proposed strategies using the formula (Pfohl, Gallus and Thomas, 2011):

$$
\begin{aligned}
& \mathrm{TE}_{\mathrm{k}}=\sum_{j} \mathrm{ARP}_{j} \mathrm{E}_{\mathrm{jk}} \quad \forall k \ldots \ldots \ldots . .(2) \\
& \text { with } \\
& \mathrm{TE}_{\mathrm{k}} \quad=\text { Total effectiveness handling } k \\
& \mathrm{E}_{\mathrm{jk}}=\text { Relationship between handling } k \text { with agent } j
\end{aligned}
$$

\section{d. Calculation of Effectiveness to Difficulty Ratio}

Calculation of the Effectiveness to Difficulty (ETDk) Ratio of the proposed treatment strategy was obtained from Total Effectiveness (TEk) compared to the Degree of Difficulty (Dk) rating. Calculation of Effectiveness to Difficulty (ETDk) Ratio of all handling strategies proposed using the formula [10]:

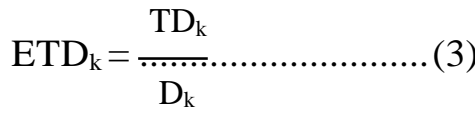

The calculation results are written in the phase 2 HoR table, where in the phase 2 HoR table, companies can find out the handling strategies that are considered effective to reduce the probability of risk agents. The choice of handling strategies by the company can be seen based on ranking by looking at the value of the existing ETD. This ranking serves to show a handling strategy that can be applied first.

\section{Research Method}

Analysis and mitigation of strategic risk of business process by considering relationship between risk was developed early by brainstorming between all departments that involved in manage the business process. There were 5 departments that involved in peer group discussion. Those departments were operation department, maintenance department, engineering department, logistic department, and finance \& HRD department. This peer group discussion was led by risk management section as a part of engineering department. In this peer group discussion, risk event and severity of risk event from KPI that potentially would not be achieved in 5 years strategic planning base on four perspective balance scorecard business process would be identified. After that participant identified risk agent and occurrence risk agent as the cause of the emergence of risk events using guidance severity and occurrence table from company $\mathrm{X}$.

Next step, prioritized risk agent using HOR 1 still was in the same forum group discussion, and the same participant in this step would guide to look at the relationship risk agent to risk event to obtained ARP by multiply of the severity, occurrence and value of the relationship between risk agents with risk events. 
Figure 1. Research Flow Chart

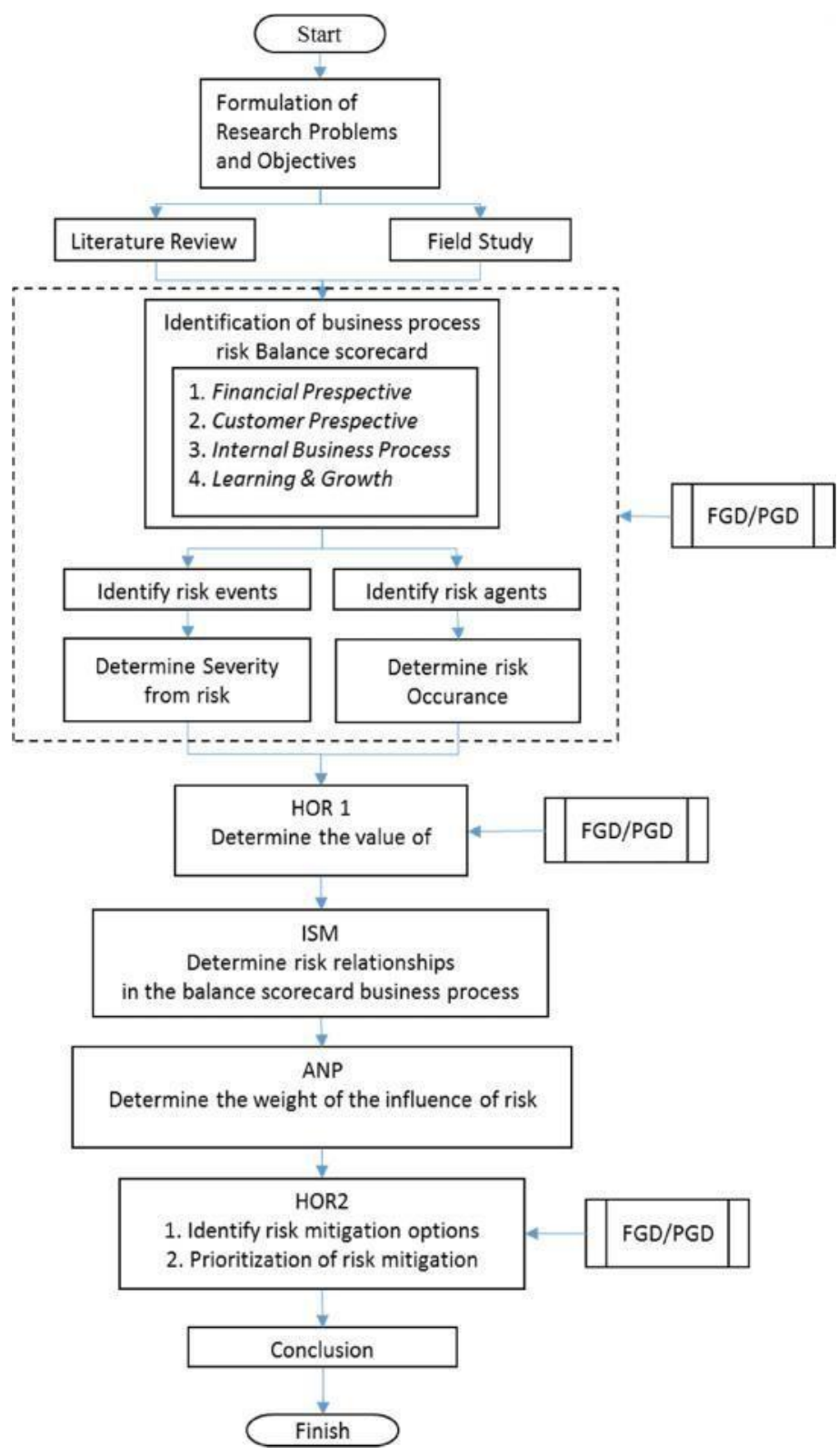

After all risk events and risk agent were identified, next step was prioritized risk agent using House of risk 1 was still in the same forum group discussion and the same participant in this step would guide to look relationship risk agent to risk event to obtained ARP by multiply of the severity, occurrence and value of the relationship between risk agents with risk events.

Prioritized risk product from HOR1 would be used in interrelationship analysis with interpretive structural modeling. In this step, the management of company $\mathrm{X}$ would involve to give judgment risk relationship in management meeting. Step by step process to make ISM diagram had already been explained in literature review.

ISM diagram was adopted in network model in analytic network process for further analysis of the 
weighted relationship network to look how significant one risk would influence another risk in relationship network. Output from this method would create new ARP value that already considered interrelationship weighted risk.

From the results of the ARP values obtained from ANP analysis, then risk mitigation was designed to minimize the use problem or risk agent so that it could improve the mitigation actions of the company using House of risk 2. Sequential step can be described in figure 1.

\section{Result and Discussion}

Based on the results of the initial mapping by risk management section of company $\mathrm{X}$ on the KPI strategic business processes that referred to the balance scorecard, 20 KPIs were obtained which could potentially not be achieved in the strategic planning projections for the next 5 years which were then called risk events. The example of one of the perspectives of the balance score card from the other 4 balance scorecard perspectives containing the KPI can be seen in the table 1 below.

Table. 1 KPI Balance Scorecard

\begin{tabular}{|c|c|c|c|}
\hline $\begin{array}{c}\text { BSC } \\
\text { Perspective }\end{array}$ & $\begin{array}{l}\text { Strategic } \\
\text { Objective }\end{array}$ & Description & $\begin{array}{l}\text { Potential } \\
\text { KPI }\end{array}$ \\
\hline \multirow{3}{*}{ 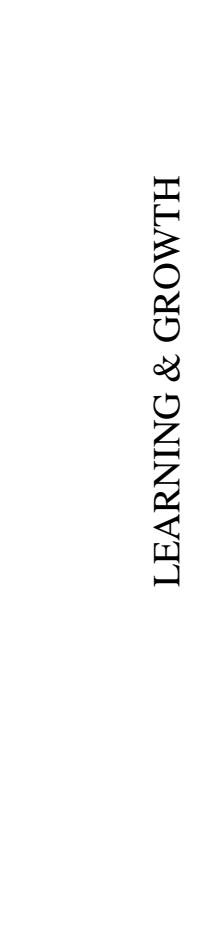 } & L1 & $\begin{array}{l}\text { Ensuring the availability of human } \\
\text { resources for units in terms of capacity and } \\
\text { capability in accordance with the needs of } \\
\text { the plant in a timely manner by utilizing the } \\
\text { integration of other subsidiaries. The unit } \\
\text { will also support corporations in developing } \\
\text { HR for the preparation of new/other units, } \\
\text { e.g. HR training }\end{array}$ & $\begin{array}{l}\text { MW/employee } \\
\text { (compared to } \\
\text { similar plants) }\end{array}$ \\
\hline & L2 & $\begin{array}{l}\text { Strengthening the ability of employee } \\
\text { asset management in implementing } \\
\text { standardized governance and operating } \\
\text { a technology system }\end{array}$ & $\begin{array}{l}\% \text { TNA / Actual } \\
\text { Training }\end{array}$ \\
\hline & L3 & $\begin{array}{l}\text { Enhancing the capabilities and integrated IT } \\
\text { processes that are good as enablers in } \\
\text { delivering the required information quickly, } \\
\text { accurately, and efficiently, to assist in } \\
\text { decision making }\end{array}$ & $\begin{array}{l}\text { SLA for Service } \\
\text { Management }\end{array}$ \\
\hline
\end{tabular}

The results of the risk event mapping from the KPI on the four balance scorecard perspectives were then determined to determine the cause of the risk event by involving all fields related to the process owner in the company $\mathrm{X}$ in an FGD forum coordinated by the risk management section. Using preliminary identification of risk events that might emerge, the FGD was able to identified 87 risk agents completed 
with occurrence rates. One example of several risk agents that caused risk events in one of the balance scorecard perspectives can be seen in table 2 below.

Table 2 Risk event severity and risk agent occurrence

\begin{tabular}{|c|c|c|c|c|c|c|}
\hline Perspective & $\begin{array}{l}\text { Strategic } \\
\text { Objective }\end{array}$ & $\begin{array}{l}\text { Event } \\
\text { Risk }\end{array}$ & Severity & Code & $\begin{array}{c}\text { Risk } \\
\text { Agent }\end{array}$ & Occurrence \\
\hline \multirow{4}{*}{ לָ } & \multirow{4}{*}{ 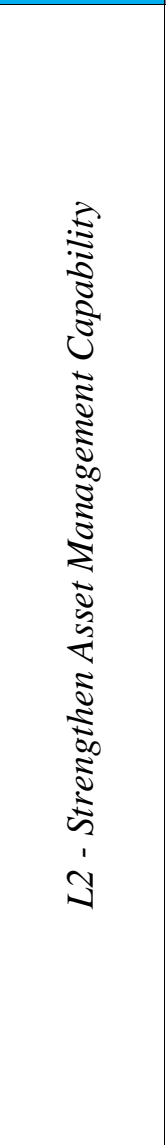 } & \multirow{4}{*}{ 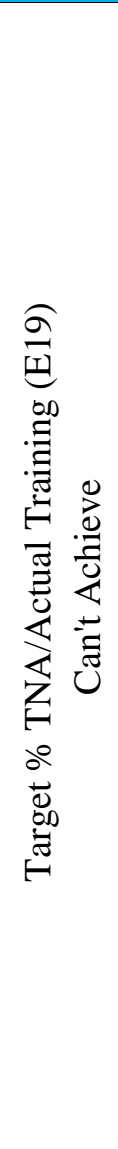 } & \multirow{4}{*}{0.4} & A 80 & $\begin{array}{l}\text { High employee turnover } \\
\text { due to the large number } \\
\text { the development of new } \\
\text { units in PJB has the potential } \\
\text { to cause loss of critical } \\
\text { competence }\end{array}$ & 0.7 \\
\hline & & & & A81 & $\begin{array}{l}\text { The new employees } \\
\text { recruited are all from fresh } \\
\text { graduates who have no } \\
\text { experience in the field of } \\
\text { electricity generation so } \\
\text { that adaptation time is } \\
\text { needed for the operation } \\
\text { and maintenance of high- } \\
\text { tech plants }\end{array}$ & 0.7 \\
\hline & & & & A82 & $\begin{array}{l}\text { The lack of optimal } \\
\text { measurement of employee } \\
\text { competence to the level of } \\
\text { work performed }\end{array}$ & 0.7 \\
\hline & & & & A83 & $\begin{array}{l}\text { The unavailability of } \\
\text { specific training that is } \\
\text { suitable with the needs } \\
\text { of the generating staff }\end{array}$ & 0.7 \\
\hline
\end{tabular}

Still in the same forum involving all areas of the owner's process, from the risk events of 20 risk events related to the level of severity and risk agents, 87 risk agents related to the level of occurrence have been identified. Risk agent prioritization using House of Risk 1 was conducted by calculating the potential risk aggregate value obtained from the results of the severity, while occurrence and value of the relationship between risk agents with risk events was determined according to the House of risk 1 calculation. The Aggregate Risk value then sought the biggest potential (ARP) of $30 \%$ cumulative according to the Pareto principle so that 17 risk agents are obtained with the largest cumulative 30\% ARP value. This value can be seen in table 3. 
Table 3. Pareto Value ARP of Risk Agent

\begin{tabular}{|c|c|c|c|c|c|}
\hline NO & $\begin{array}{l}\text { BSC } \\
\text { PRESPECTI } \\
\text { VE }\end{array}$ & $\begin{array}{l}\text { RISK } \\
\text { AGEN } \\
\text { T } \\
\text { CODE }\end{array}$ & DESCRIPTION & $\mathbf{A R P}$ & $\begin{array}{l}\text { ARP } \\
\text { CUMULATIV } \\
\text { E }\end{array}$ \\
\hline 1 & I6 & A74 & $\begin{array}{l}\text { No measurement and evaluation of the effectiveness of } \\
\text { the current PM is carried out }\end{array}$ & 34.72 & 34.72 \\
\hline 2 & $\mathrm{~L} 2$ & A80 & $\begin{array}{l}\text { High employee turnover due to the large number the } \\
\text { development of new units in PJB has the potential to } \\
\text { cause loss of critical competence }\end{array}$ & 30.24 & 64.96 \\
\hline 3 & L3 & A79 & $\begin{array}{l}\text { Ineffective team work between functional organization, } \\
\text { seeing silo-silo sector KPIs }\end{array}$ & 29.68 & 94.64 \\
\hline 4 & $\mathrm{~S} 1$ & A26 & $\begin{array}{l}\text { Operation unit without comply with Environment } \\
\text { Regulation HSE regulation. }\end{array}$ & 27.72 & 122.36 \\
\hline 5 & $\mathrm{I} 2$ & A43 & $\begin{array}{l}\text { Business processes have not been effective, business } \\
\text { processes of each field cannot be utilized by other } \\
\text { related fields }\end{array}$ & 27.72 & 150.08 \\
\hline 6 & $\mathrm{~F} 1$ & $\mathrm{~A} 1$ & $\begin{array}{l}\text { Sales declined due to high equipment damage due to } \\
\text { Poor maintenance planning \& execution }\end{array}$ & 27.44 & 177.52 \\
\hline 7 & $\mathrm{~S} 2$ & A33 & $\begin{array}{l}\text { Preventive maintenance is not effective (the amount of } \\
\text { corrective maintenance work that appears) }\end{array}$ & 27.16 & 204.68 \\
\hline 8 & I6 & A71 & The quality of PM / OH job standards is not on target & 27.16 & 231.84 \\
\hline 9 & $\mathrm{I} 3$ & A51 & Insufficient availability of critical parts & 26.46 & 258.3 \\
\hline 10 & I5 & A65 & $\begin{array}{l}\text { processing installations waste not ready due to lack of } \\
\text { optimal pre-maintenance and predictive maintenance in the } \\
\text { waste treatment plant area }\end{array}$ & 26.04 & 284.34 \\
\hline 11 & S1 & $\mathrm{A} 23$ & $\begin{array}{l}\text { The inability of the unit to meet the requested power } \\
\text { due to equipment disruption }\end{array}$ & 25.76 & 310.1 \\
\hline 12 & I5 & A61 & $\begin{array}{l}\text { The amount of fire protection system damage because, } \\
\text { there is no PM schedule and PM job standard for K3 } \\
\text { equipment }\end{array}$ & 24.64 & 334.74 \\
\hline 13 & $\mathrm{I} 3$ & A50 & $\begin{array}{l}\text { Error in predicting sales so there is a possibility of Supply } \\
\text { shortages or excess fuel supply }\end{array}$ & 22.96 & 357.7 \\
\hline 14 & L3 & A85 & $\begin{array}{l}\text { IT infrastructure that has not been integrated, } \\
\text { there is still a missing link between business processes }\end{array}$ & 22.68 & 380.38 \\
\hline 15 & $\mathrm{~S} 2$ & A28 & $\begin{array}{l}\text { The duration of } \mathrm{OH} \text { work increases because a lot of } \\
\text { additional scope of work is beyond the initial planning }\end{array}$ & 21.84 & 402.22 \\
\hline 16 & I5 & A59 & $\begin{array}{l}\text { mapping and scheduling of RLA and LCCM } \\
\text { have not been well structured and scheduled }\end{array}$ & 21.28 & 423.5 \\
\hline 17 & I1 & A40 & $\begin{array}{l}\text { Social mapping already exists and the budget is available } \\
\text { but personnel who will carry out assistance in } \\
\text { implementing the program do not yet have sufficient } \\
\text { knowledge and competencies for assistance, } \\
\text { communication and program execution }\end{array}$ & 20.58 & 444.08 \\
\hline
\end{tabular}

Based on the pareto results of the ARP House of Risk 1 value, 17 risk agents were found to have a significant effect on the potential for non-achievement of Strategic KPIs on the four balance scorecard perspectives.

From the 17 risk agents, further analysis was carried out to see the relationship between risk agents using the method of interpretive structural modeling through plenary during management review meetings involving the General Manager as the highest leader in the Company $\mathrm{X}$ and Department managers consisting of operations managers, maintenance managers, engineering managers and quality assurance, logistics managers, administrative managers-financial management as representatives of fields that have 
KPIs on four balance scorecard perspectives, and also supervisors risk quality and performance management as a risk management section in Company $\mathrm{X}$.

From the analysis using the interpretive structural modeling method through the Structural SelfInteraction Matrix (SSIM) stages, Reachievability matrix, canonical matrix, and power dependence matrix driver, 7 risk agents in the driver area were obtained, namely risk agents A79, A80, A85, A43, A51, A74, A71 which have strong influence on the risk dependence agent A59, A65, A61, A33, A28, A26, A23, A50, $\mathrm{A}$, and 1 risk agent in the autonomous area, namely risk agent A40. Based on these results, there were 7 levels of levels from the 17 risk agents that were related to the risks in Figure 2 of the ISM digraph diagram.

Figure 2. ISM Diagram

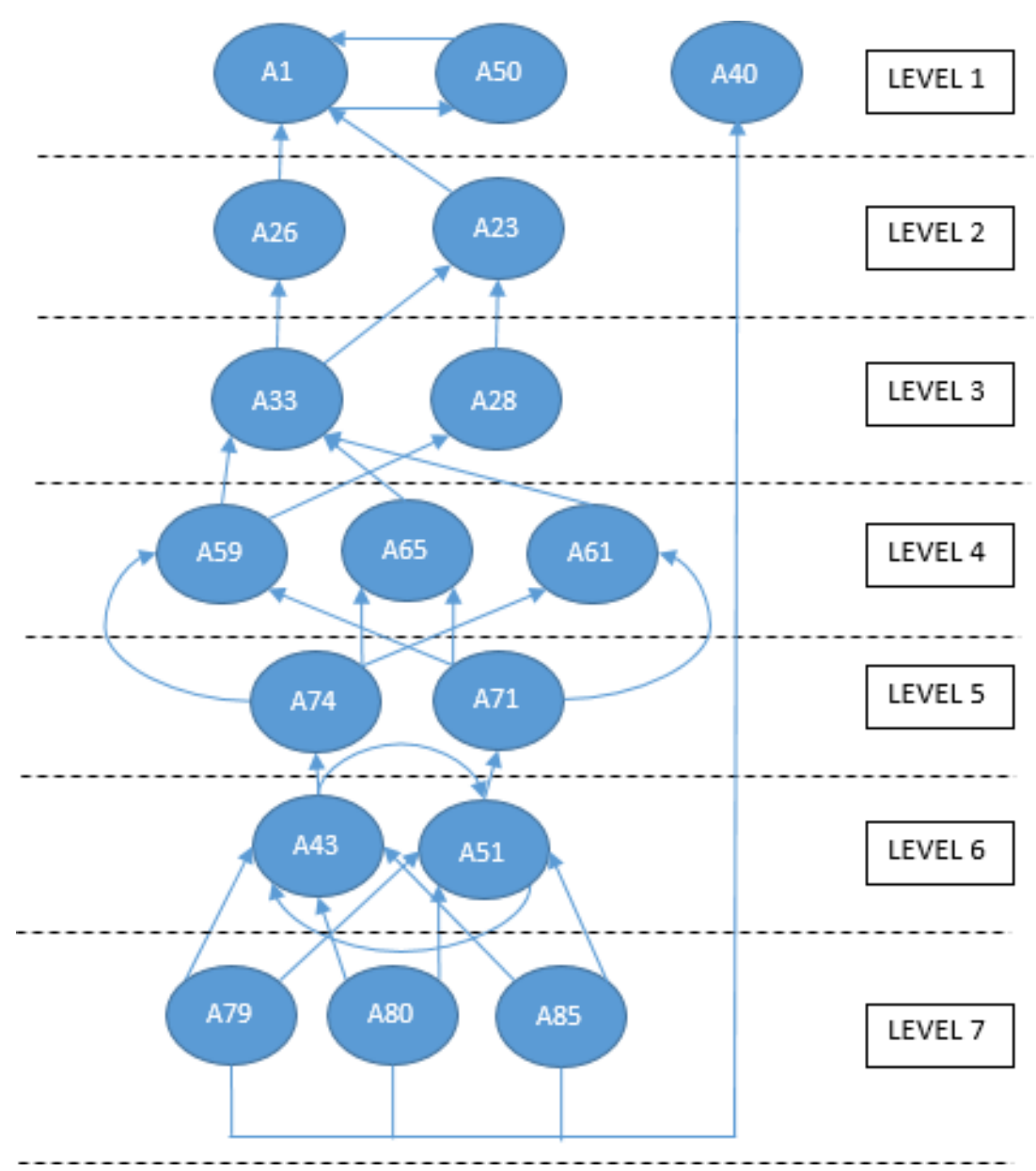

The next stage was to see how influential the causes of risk influenced other risks, a link diagram on ISM diagram figure 3 was used in analytic network process using super decision 2.0 software obtained by super matrix analysis of paired wise comparisons obtained from company team management meetings involving the general manager as top management of company $\mathrm{X}$ and 5 department managers in charge of the process owner's parts and representing the four balance scorecard perspectives. Those five managers 
were operation managers, maintenance managers, logistics managers finance managers, and HRD managers. The results of ANP network compilation from the ISM analysis can be seen in Figure 3.

Figure 3 . Model Network for Risk Agent Relationship in ANP

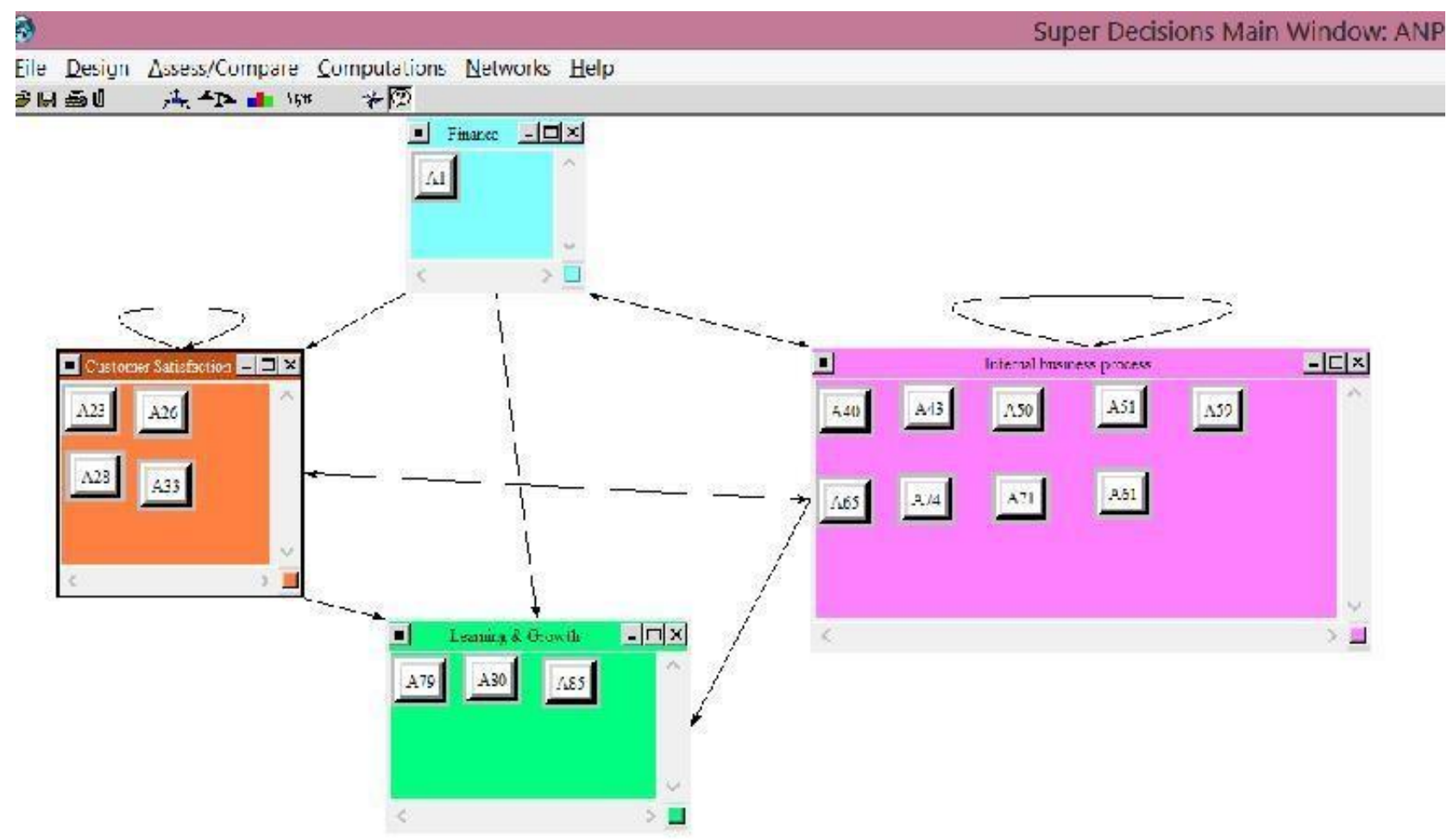

The paired comparisons performed should meet the requirement that the Consistency Index CI is below 0.1. From the results of ANP weighting, a new ARP value composed of the weight values of the causes of risk that affected it was obtained. This can be illustrated in the following Figure 4 and 5 .

Figure 4. The initial ARP value before the relationship between risks

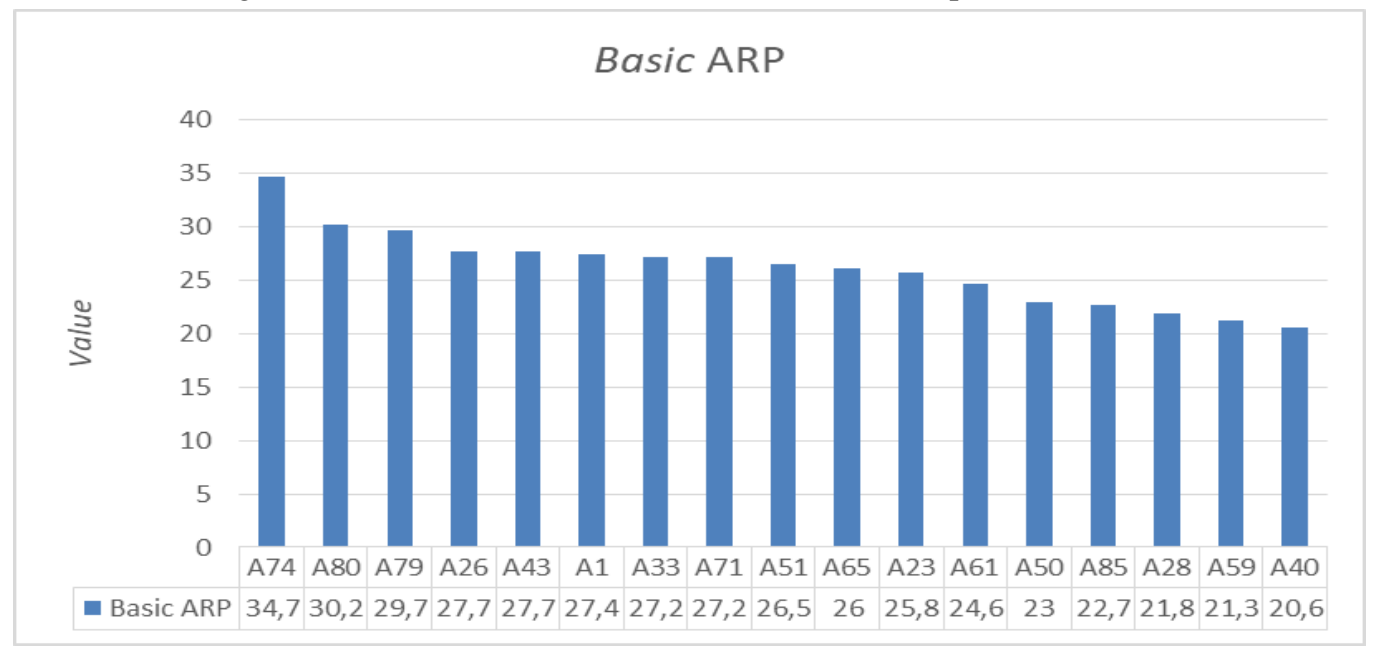




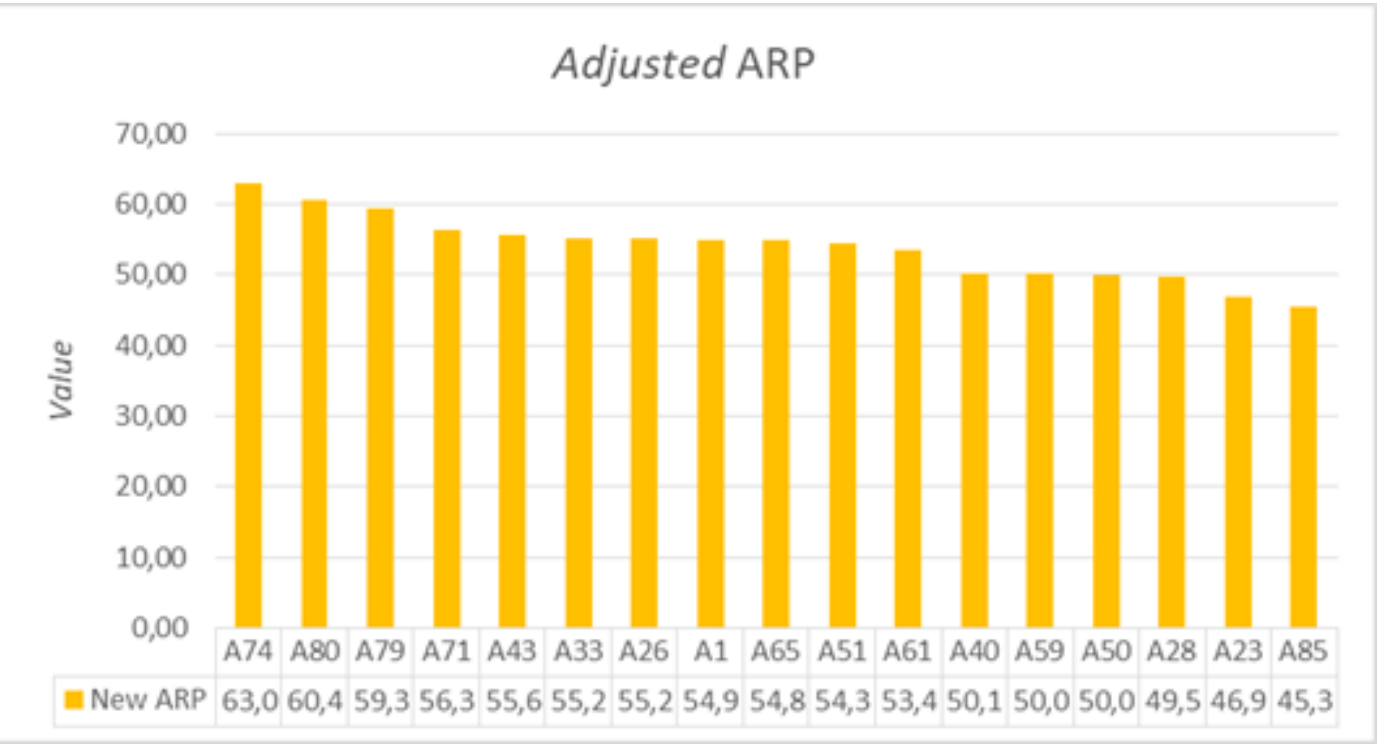

Figure 5. The adjusted ARP value after the relationship between risks

From the results of the ARP values obtained from ANP analysis, then risk mitigation was designed to minimize the use problem or risk agent so that it could improve the mitigation actions of the company well. The next stage was to discuss in the forum again with the same participants in the HOR FGD1 sections related to the company's business processes. From this FGD, 8 precautionary measures were obtained as mitigation efforts. The 8 preventive measures are listed in Table 4.

Table 4. Preventive Action Risk Agent Selected

\begin{tabular}{|c|c|c|}
\hline No & PREVENTIVE ACTION & CODE \\
\hline 1 & Knowledge Loss Risk Assessment & PA1 \\
\hline 2 & $\begin{array}{l}\text { Optimizing the Preventive / Predictive Maintenance } \\
\text { Control Process using WEB-based NFC - RFID } \\
\text { Technology }\end{array}$ & PA2 \\
\hline 3 & $\begin{array}{l}\text { Work Package maintenance for K3 \& Environmental } \\
\text { equipment }\end{array}$ & PA3 \\
\hline 4 & $\begin{array}{l}\text { LCCA use RAMS Modeling } \\
\text { based on CMMS data }\end{array}$ & PA4 \\
\hline 5 & SLA scheme between department and section & PA5 \\
\hline 6 & Enterprise Architecture & PA6 \\
\hline 7 & Web RLA & PA7 \\
\hline 8 & Long Term Service Agreement and Multiyear contract & PA8 \\
\hline
\end{tabular}


The second phase of the HoR calculation was performed to get the sequence of program effectiveness priorities (TE) by multiplying between the ARP value and the correlation value between preventive action and the chosen risk agent. Furthermore, each program had a level of ease of implementation (D) with a scale of 3 (low), 4 (moderate), and Appendi5 (high). The program implementation effectiveness ratio (ETDk) was obtained by dividing the TE value by $\mathrm{D}$, and the highest value became a work program with the first priority.

House of Risk 2 calculation raised the results of the order of priority for selected preventive actions that had to be done to mitigate strategic risks in company X. This is presented in table 5. This program of the eight preventive measures may be carried out by the company's management in mitigating strategic risk.

Table 5. Selected Preventive Action Priorities

\begin{tabular}{|c|c|c|c|}
\hline $\begin{array}{l}\text { Order } \\
\text { Priority }\end{array}$ & CODE & PREVENTIVE ACTION & ETD \\
\hline 1 & PA2 & $\begin{array}{l}\text { Optimizing the Preventive / Predictive Maintenance } \\
\text { Control Process using WEB-based NFC - RFID } \\
\text { Technology }\end{array}$ & 1033.34 \\
\hline 2 & PA4 & $\begin{array}{l}\text { LCCA use RAMS Modeling } \\
\text { based on CMMS data }\end{array}$ & 1009.72 \\
\hline 3 & PA1 & Knowledge Loss Risk Assessment & 869.26 \\
\hline 4 & PA6 & Enterprise Architecture & 847.31 \\
\hline 5 & PA5 & SLA scheme between department and section & 781.19 \\
\hline 6 & PA8 & Long Term Service Agreement and Multiyear contract & 573.22 \\
\hline 7 & PA7 & Web RLA & 392.76 \\
\hline 8 & PA8 & $\begin{array}{l}\text { Work Package maintenance for K3 \& Environmental } \\
\text { equipment }\end{array}$ & 380.69 \\
\hline
\end{tabular}




\section{Conclusion}

Based on the results of the strategic risks of business processes identification using four balance scorecard perspectives, 20 risk events that potentially could not be achieved by the KPI as determined in the next five years' strategic planning were identified. These 20 risk events might be caused by 87 risk agents. The risk-causing agent prioritization was carried out using the Pareto principle based on the Aggregate Risk Potential (ARP) value obtained from the calculation of house of risk 1, resulting 17 risk agents which had a significant effect on the possibility of not achieving the specified KPI's targets. This was further analyzed using the interpretive structural modelling (ISM) method to see the relationship between risk agents, so that a relationship diagram between risks was obtained in the form of a 7 level ISM diagram consisting of 9 risks in a strong driver power area affecting 7 other risks in the dependent area and 1 risk that was in the autonomous region. The ISM diagram was then weighted using the Analytic Network Process (ANP) method for the 17 risk agents so that the ARP amount was adjusted by considering the relationship between the risk and the weight of each risk which could later be mitigated against the risk agent comprehensively to produce effective action for the company so that the business processes carried out by the company could achieve the planned KPI's targets. As for the results of risk mitigation analysis using the House of Risk 2 method, 8 preventive actions that were considered effective in accordance with the order of priority scale were obtained, namely: optimizing preventive/predictive maintenance control processes using NFC web-based technology, LCCA using CMMS data based on RAMS modelling, conducting knowledge loss risk assessment, developing enterprise architects, making SLAs between departments, implementing long term service agreement and multi-year contracts, utilizing RLA web, making maintenance work packages for K3 and the environment equipment.

For further research, the writer suggests that the relationship between risks using the House of Risk, ISM and ANP methods can be applied to other generation units in company $\mathrm{X}$ work area or similar industries in addition to the case studies in this study in order to obtain a comprehensive picture of the risks that might arise in a company.

In addition, the relationship between risks using the ISM method and the help of experts in analyzing the driving and dependence variables of the problem or issue statistically was not validated, so the writer suggests for future research to look at the relationship between risks suggested using the known Structural Equation Modeling model as a linear structural relationship approach that has the ability to test hypothesis model validity statistically.

\section{References}

B. \&. K. S. Rehder, "Causal status and coherence in causal knowledge affects classification: A generative theory of categorization," Journal of experimental psychology learning memory and cognition, no. 36(5), pp. 659-683, 2010.

B. Rottman, "Reasoning about causal relationship: Infrences on causal networks," Psychological Bulletin, no. 140(1), pp. 109-139, 2014.

Cheng, M.M., Humpreys, K.A and Zhang, Y.Y., "The Interplay between strategic risk profiles and presentation format on managers strategic judgments using the balance scorecard," Accounting, Organization and Society, vol. Xxx, pp. 1-14, 2018. 
F. H. P. \&. W. D. Hodge, "The effect of financial statement information proximity and feedback on cash flow forecasts," Contemporary acounting research, no. 27, pp. 101-103, 2010.

G. Talebnia, "The major perspectives weighted model for balanced scorecard system in the case of auto industries," Indian Journal of Science and Technology, vol. V, no. 10, pp. 3412-3420, 2012.

Kaplan, R.S. and Norton, D.P., "The balanced scorecard. Measures that drive performance," Harvard Business Review, no. 69(1), pp. 71-79, 1996.

L. Maines, "Effect comperhensife," The accounting review, no. 75(2), pp. 179-207, 2000.

R. Simons, Performance measurement and control systems for implementing strategy, Englewood Cliffs: Prentice Hall, 2000.

PT. Pembangkitan Jawa Bali, Asset Management, Surat Keputusan Direksi Nomor 122, PT.PJB, 2016

Pujawan, I.N. and Geraldin, L.H., "House of risk: a model for proactive supply chain risk management," Bussiness Process Management Journal, V o 1. 15, no.2, pp. 953-967, 2009.

Pfohl, Gallus and Thomas, "Interpretive structural modeling of supply chain risks," International Journal of Physical Distribution \& Logistics Management, vol. 41, pp. 839-859, 2011. 